\title{
Identification of a potent herbal molecule for the treatment of breast cancer Srinivas Koduru ${ }^{1}$, Srinivasan Sowmyalakshmi ${ }^{1}$, Raj Kumar ${ }^{1}$, Rohini Gomathinayagam ${ }^{1}$, Jürgen Rohr ${ }^{2}$ and Chendil Damodaran*1
}

\author{
Address: ${ }^{1}$ Department of Clinical Sciences, College of Health Sciences, University of Kentucky, Lexington, KY- 40536, USA and ${ }^{2}$ Department of \\ Pharmaceutical Sciences, College of Pharmacy, University of Kentucky, Lexington, KY- 40536, USA \\ Email: Srinivas Koduru - srinivas.koduru@uky.edu; Srinivasan Sowmyalakshmi - ssrin3@uky.edu; Raj Kumar - rkuma4@uky.edu; \\ Rohini Gomathinayagam - Rgoma4@uky.edu; Jürgen Rohr - jrohr@uky.edu; Chendil Damodaran* - dchen2@uky.edu \\ * Corresponding author
}

Published: 30 January 2009

BMC Cancer 2009, 9:4I doi:10.1 |86/|47|-2407-9-4|
Received: 16 July 2008

Accepted: 30 January 2009

This article is available from: http://www.biomedcentral.com/ |47/-2407/9/4 I

(c) 2009 Koduru et al; licensee BioMed Central Ltd.

This is an Open Access article distributed under the terms of the Creative Commons Attribution License (http://creativecommons.org/licenses/by/2.0), which permits unrestricted use, distribution, and reproduction in any medium, provided the original work is properly cited.

\begin{abstract}
Background: Breast cancer (BCa)-related mortality still remains the second leading cause of cancer-related deaths worldwide. Patients with $\mathrm{BCa}$ have increasingly shown resistance and high toxicity to current chemotherapeutic drugs for which identification of novel targeted therapies are required.
\end{abstract}

Methods: To determine the effect of PDBD on BCa cells, estrogen-receptor positive (ER $\left.{ }^{+}\right)-M C F-$ 7 and estrogen-receptor negative (ER-)-MDA 23 I cells were treated with PDBD and the cell viability, apoptotic, cell cycle, Western blot and Promoter assays were performed.

Results: PDBD inhibits cell viability of $\mathrm{ER}^{+}$and $E \mathrm{R}^{-} \mathrm{BC}$ a cells by inducing apoptosis without causing significant toxicity in normal breast epithelial cells. While dissecting the mechanism of action of PDBD on BCa, we found that PDBD inhibits Akt signaling and its downstream targets such as NF$\kappa B$ activation, IAP proteins and Bcl-2 expression. On the other hand, activation of JNK/P38 MAPKmediated pro-apoptotic signaling was observed in both $E R^{+}$and $E R-B C a$ cells.

Conclusion: These findings suggest that PDBD may have wide therapeutic application in the treatment of BCa.

\section{Background}

Patients with estrogen receptor-negative breast cancer (ER$\mathrm{BCa}$ ) have a median survival of 10-12 months when compared to patients with for ER-positive $\left(\mathrm{ER}^{+}\right) \mathrm{BCa}$ who have a median survival of 40-48 months [1]. Limited effectiveness of current chemotherapeutic drugs such as tamoxifen, paclitaxel and docetaxel, shows severe side effects in the BCa patients [2], these realities underscore the importance of identifying novel targeted therapies with minimal side effects to treat this deadly disease.
Akt plays a major role in the regulation of cell survival, apoptosis, and oncogenesis [3]. Activation of Akt negatively regulates the programmed cell death signaling either by blocking or inhibiting the pro-apoptotic proteins such as BAD, Forkhead transcription factors and GSK-3 $\beta$ [3-5]. The observations from cell culture studies suggests that activation of Akt leads to the phosphorylation of IKK which in turn results in NF- $\mathrm{KB}$ activation and cell survival [6]. Akt regulates cell cycle by phosphorylating the cell cycle inhibitors p21 and p27 resulting in 
uncontrolled cell proliferation in various cell types [7-9]. Additionally, Akt increases cyclin D1 expression thereby aiding cancer cell growth and proliferation [10].

Mitogen activated protein kinases (MAPKs) which are serine/threonine protein kinases involved in carcinogenesis due to their ability to stimulate cell proliferation and survival [11]. Three major subfamilies have been described: extracellular-regulated kinases (ERK), c-Jun N-terminal kinase (JNK), and p38 kinase; depending on the cellular context and stimulators these signaling pathways will be activated following phosphorylation of downstream events which will decide the fate of the cell. In the MAPK pathway, the small G-protein, Ras activates Raf- 1 which in turn activates MEK-1 resulting in the activation of $\mathrm{p} 44$ (ERK1) and p42 (ERK2) which is known to cause cellular proliferation and inhibit apoptosis [12]. However, growing evidence suggesting the dual role of the MEK/ERK pathway in cell survival and apoptosis [13]. On the other hand, JNK and p38 kinases are generally involved in the regulation of pro-apoptotic signaling in many cell types [14].

Current therapeutic modalities for BCa are usually associated with toxicity and side effects thereby indicating novel targeted therapies are much needed. Recently, much attention is being paid to natural compounds and several groups have demonstrated their usefulness either for chemoprevention or chemotherapy on BCa. The lack of mechanistic details about these compounds has impeded bringing them to the main stream of medicine for prevention or treatment of BCa. Naturally occurring polyphenolic antioxidants are recognized as one of the most effective classes of cancer-preventive agents [15-17], because they reduce oxidative stress a known contributor to carcinogenesis with little or no systemic toxicity [18]. Work in our laboratory is focused on dissecting the mechanism of action of natural compounds and more importantly, to discover promising lead components for the development of anti-cancer drugs that specifically target BCa. Recently, we reported that a polyherbal medicine is currently in practice as complementary and alternative therapy for the treatment of $\mathrm{BCa}$ in the southern parts of India [19], which were shown to inhibit $\mathrm{ER}^{+}$and ER- BCa cells in cell culture models [19]. We have isolated an active ingredient, ( $8^{\prime} Z$ )-3-pentadec-10-enyl-benzene-1, 2diol (PDBD) from this polyherbal mixture which has proved to be effective on BCa cells [20]. This study is focused on determining the molecular mechanism of action of PDBD on BCa.

\section{Methods \\ Cell lines}

MCF-10A, MDA 231, MCF-7, ZR-75-1, Hs578T and MDA 435 cells were purchased from American Type Culture
Collection (Manassas, VA). All the cell lines were grown in DMEM supplemented with $10 \%$ fetal bovine serum and $1 \%$ L-glutamine.

\section{Natural compounds and caspase inhibitor}

(8'Z)-3-pentadec-10-enyl-benzene-1, 2-diol (PDBD) was the major compound isolated from Polyherbal mixture in the Dr. Rohr's laboratory at the University of Kentucky with a purity of $99.5 \%$ (Figure 1) [20]. Caspase-3 inhibitor, zDEVD-CHO was purchased from Promega Corporation (Madison, WI).

\section{Cell viability, Apoptotic assays and Cell Cycle analysis}

Cells were treated with PDBD or vehicle (DMSO) for $24 \mathrm{~h}$ at different concentrations and cell survival curve was plotted using MTT assay [21]. Also, Annexin V-FITC staining assays and TUNEL assays were performed on five different BCa cells and treated with 4,6 or $8 \mu \mathrm{M}$ PDBD followed by flowcytometric analysis as described earlier $[22,23]$. Cell cycle analysis in MCF-7 and MDA 231 cells was performed following treatment with PDBD $(3 \mu \mathrm{M}$ and $2 \mu \mathrm{M}$ respectively) using flow cytometric analysis as described earlier [22].

\section{Western Blot analysis}

MDA 231 and MCF-7 cells were treated with PDBD (4 and $6 \mu \mathrm{M}$, respectively) for varying time intervals and cell lysates were subjected to Western blot analysis using Akt, ERK, pERK1/2, MEK-1, MEK-4, MEKK-1， pMEK-1/2, pMEK-3/6, Bcl-2, survivin, cdk-2, cdk-4, cdk-6, cyclin D1, cyclin E and NF- $\kappa B$ subunits p50, p55 and p65 from Santa Cruz Biotechnology (Santa Cruz, CA); XIAP and Bcl-xL from MBL International (Woburn, MA) and, pAkt (ser 473), PI3K p85 and Histone H3 from Cell signaling technology (Danvers, MA). $\beta$-actin and GAPDH from Santa Cruz Biotechnology was used as the loading control.

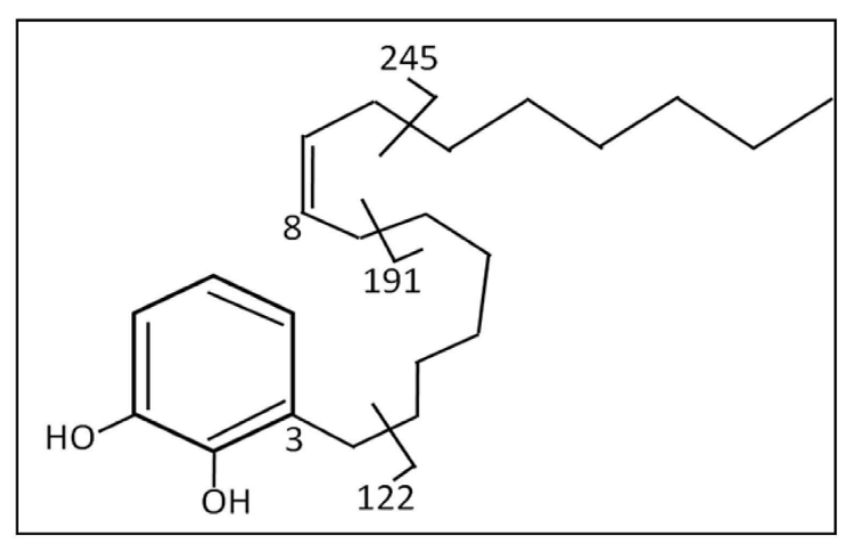

Figure I

Structure of [(8'Z)-3-pentadec-I 0-enyl-benzene-I, 2diol (PDBD). 


\section{Kinase assay}

PI3 kinase assay was also performed to determine the effect of PDBD on PI3K expression and activity. PDBDand vehicle-treated cells were subjected to PI3 kinase assay using colorimetry as described earlier [24].

\section{ELISA for IKB- $\alpha$ activity}

MDA 231 cells were treated with PDBD for 6 and 12

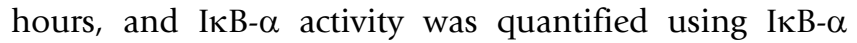
ELISA kit (Calbiochem, Gibbstown, NJ) as described earlier [24].

\section{ELISA studies for NF- $\kappa$ B activity}

MDA 231 cells were treated with PDBD for 6 and 12 hours, and binding studies were performed to determine the activity of NF- $\mathrm{B}$ p 65 subunit using universal EZ-TFA transcription factor assay kit (Millipore, Bedford, MA) as described earlier [25].

\section{Transient transfection and luciferase assay}

MDA 231 cells (at 70-80\% confluency) were transiently transfected using Lipofectamine plus reagents from Invitrogen Corporation (Carlsbad, CA) with $4 \mu \mathrm{g}$ of the NF- $\kappa \mathrm{B}$ luciferase construct (containing two tandem repeats of $\mathrm{NF}-\kappa \mathrm{B}$-responsive sites) in the presence of a vector containing Renilla luciferase to normalize transfection efficiency as described earlier [26,27]. Transfected cells were either left untreated or treated with PDBD as indicated and the cells were harvested after $24 \mathrm{~h}$ to determine NF- $\kappa \mathrm{B}$ promoter activity.

\section{Fluorometry for caspase-3 activation}

MDA 231 cells were treated PDBD alone or caspase-3 inhibitor alone or a combination of both for $24 \mathrm{~h}$ and caspase-3 activity was determined using the ApoAlert caspase-3 fluorescent assay kit as described earlier [26].

\section{Statistical analysis}

all the experiments were performed three times to ascertain reproducibility of the results and the data shown are representative of three experiments. The student's t test was used to calculate statistical significance.

\section{Results \\ PDBD inhibits cell survival and induces apoptosis on $E R^{+}$ and $E R^{-} B C a$}

To determine the anti cancer effect of PDBD, we conducted cell viability and apoptotic assays on a panel of $\mathrm{ER}^{+}$(MCF-7 and ZR-75-1), ER- (MDA 231, MDA 435 and Hs578T) BCa and normal breast epithelial (MCF-10A) cells. As seen in figure 2A, MDA 231, Hs578t and ZR-75-1 cells were highly sensitive to PDBD when compared to MCF-7 and MDA 435 cells. Interestingly, there was no significant alteration in the viability of normal breast epithe- lial cell line, MCF-10A suggesting that PDBD selectively targets BCa cells.

To determine whether inhibition of cell viability by PDBD is due to the induction of apoptosis, all the five BCa cell lines (Hs578T, ZR-75-1, MCF-7, MDA 231 and MDA 435) and normal breast epithelial cells (MCF-10A) were subjected to Annexin V-FITC and TUNEL assays. PDBD at 8 $\mu \mathrm{M}$ concentration induced almost $100 \%$ apoptosis in MDA 231, Hs578T and ZR-75-1 when compared to 56\% and $58 \%$ of apoptosis in MCF-7 and MDA 435 cells respectively (Figure $2 \mathrm{~B}$ ). However, PDBD failed to induce significant levels of apoptosis in the normal breast epithelial cell line, MCF-10A (Figure 2B). The apoptotic index was confirmed by Annexin-V-FITC/PI and TUNEL assays.

\section{Role of PDBD in cell cycle regulation in BCa cells}

We investigated whether PDBD plays a role in the regulation of cell cycle and found that PDBD treatment induced a strong $\mathrm{G}_{0} / \mathrm{G}_{1}$ cell cycle arrest observed in time dependent manner. In MDA-231 cells, a G0/G1 phase of cell cycle distribution was $64.5 \%$ at $12 \mathrm{~h}$ following treatment with PDBD, $66.3 \%$ and $75.36 \%$ at 24 and 48 hours respectively with a concomitant decrease in the percentage of cells in the $S$ and $G_{2} / M$ phase (Table 1 ). A similar $G_{0} / G_{1}$ arrest was observed in MCF-7 cells following treatment with PDBD (Data not shown).

Next, we examined whether PDBD regulates the expression of $G_{0} / G_{1}$ cell cycle proteins in MCF-7 and MDA 231 cells. As seen in figure 3, PDBD downregulated the expression of Cdk-2, Cdk-4 and Cdk- 6 in a time dependent fashion in both MCF-7 and MDA 231 cells. In addition, Cyclin E and Cyclin D1 expressions were also downregulated following treatment with PDBD in both BCa cell lines. Collectively these observations suggest that PDBD alters the expression of $\mathrm{G}_{0} / \mathrm{G}_{1}$ regulatory proteins thereby causing cell cycle arrest in BCa cells.

\section{PDBD inhibits Akt signaling without altering PI3K activity in BCa cells}

The protein kinase, Akt, functions as a molecular nexus for a number of signaling pathways that regulate cell growth, cell survival, and tumor progression, and its activity has been implicated in the inhibition of apoptosis and promotion of angiogenesis [28]. PDBD inhibited pAkt (ser 473) expression $6 \mathrm{~h}$ after treatment in MCF-7 cells, whereas, in MDA-231 cells, inhibition of pAkt expression was seen at $24 \mathrm{~h}$ after treatment. No alteration in total Akt levels in MDA 231 cells were seen (Figure 4A). Then, we determined whether PDBD targets the upstream event of Akt, the PI3K and found that no alteration of either the expression (upper panel) or activity (lower panel) of PI3 Kinase in BCa cells (Figure 4B) were seen suggesting that PDBD specifically either Akt or its downstream signaling 

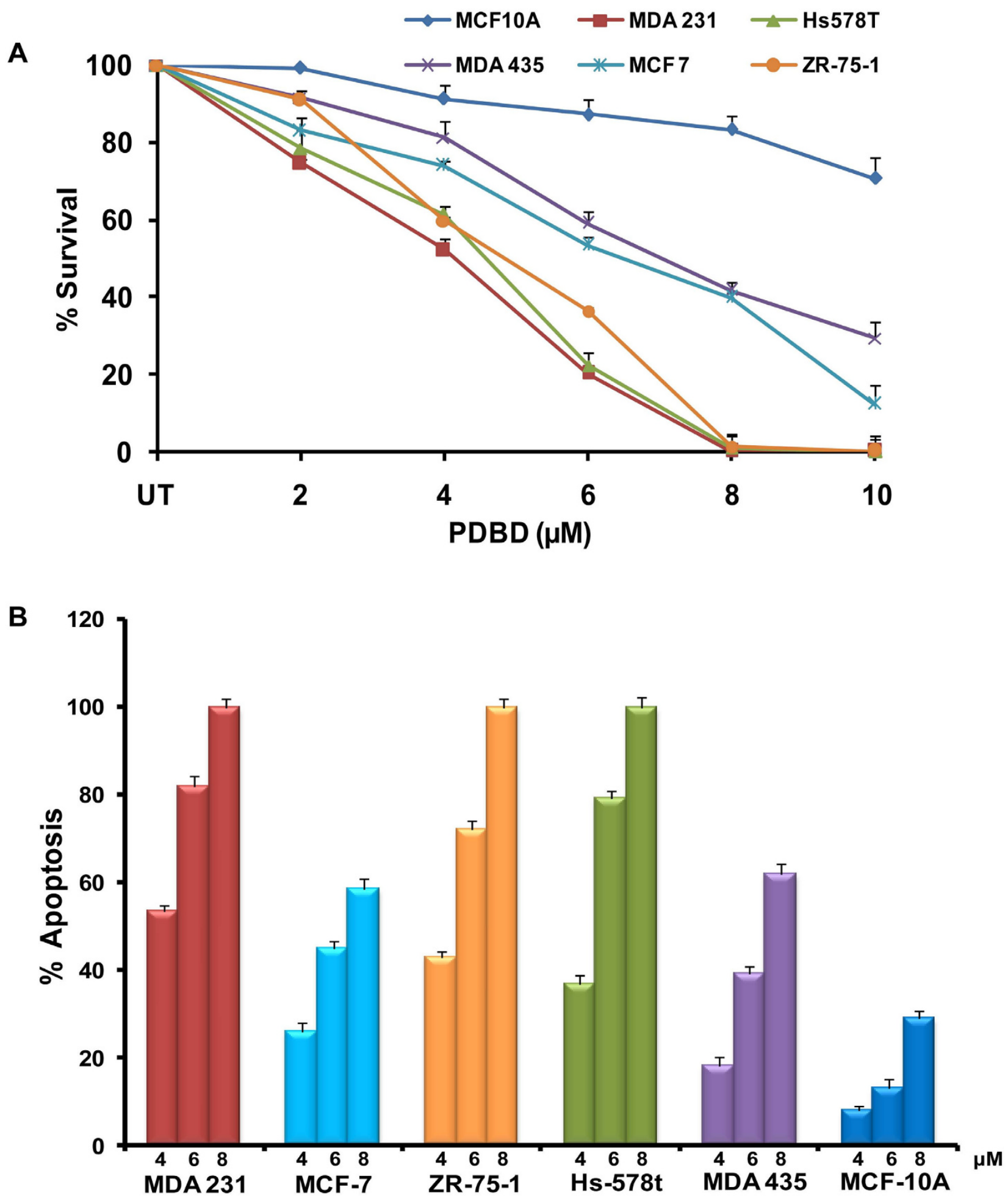

Figure 2

A. BCa cells were treated with varying concentrations of PDBD for $24 \mathrm{~h}$ and MTT assay was performed to determine cell viability. Each data point represents the mean \pm SD for four wells. B. PDBD induced apoptosis in BCa cells. Bar graph shows the percentage of apoptosis. The base-line apoptosis in the untreated group was normalized with data in the treated group. The data shown are representative of mean \pm SD from three independent experiments. 
Table I: Effects of PDBD on cell cycle distribution of PDBD.

\begin{tabular}{lcccc}
\hline Cell cycle & Treatments & \multicolumn{4}{c}{ MDA 23 I (in \%) } \\
\cline { 2 - 5 } & & I2 h & $\mathbf{2 4} \mathbf{~ h}$ & $\mathbf{4 8 ~ h}$ \\
\hline G0/G I phase & UT & 46.85 & 36.77 & 39.53 \\
\cline { 2 - 5 } & PDBD & 64.53 & 66.33 & 75.36 \\
\hline S phase & UT & 33.49 & 56.66 & 54.71 \\
\hline & PDBD & 28.14 & 33.67 & 15.77 \\
\hline G2/M phase & UT & 4.15 & 6.57 & 5.76 \\
\cline { 2 - 5 } & PDBD & 7.34 & 0.0 & 8.86 \\
\hline
\end{tabular}

of BCa. While dissecting the effect of PDBD on Extracellular-regulated kinase (ERK) signaling, we found that gradual upregulation of pERK expression was seen in MCF-7 and MDA 231 cells. Total ERK levels remained constant in both the BCa cell lines following treatment with PDBD for upto $24 \mathrm{~h}$ (Figure 5).

\section{PDBD inhibits NF- $\kappa$ B activation in MDA 231 cells}

Since there was no significant downregulation of pAkt expression in MDA 231, we investigate whether the downstream events of Akt signaling are affected by PDBD. Nuclear factor- $\kappa \mathrm{B}$ is a transcription factor which is involved in cell survival and proliferation and has been established as one of the major downstream targets of Akt [29]. PDBD down regulated NF-kB p65 activity (Figure $6 \mathrm{~A}$ ) and also inhibited NF- $\kappa \mathrm{B}$ at the promoter level (Figure 6B) in MDA 231 cells. Then, we analyzed IкB status, and our results suggest that PDBD is capable of maintaining I $\mathrm{B}$ - $\alpha$ in the non-phosphorylated form thereby inhibiting the nuclear translocation of the active NF- $\kappa \mathrm{B}$ subunits (Figure 6C). Also, as expected, a significant down regulation of NF- $\mathrm{KB}$ subunits (p65, p55 and p50) in a timely manner in the nuclear fraction suggesting that PDBD effectively inhibits NF-KB activation (Figure 6D).

\section{PDBD regulates Pro-Apoptotic and Pro-Survival Proteins in $\mathrm{BCa}$}

The Bcl-2 family of proteins and IAPs are a well established class of proteins that are involved in the regulation of cell survival and apoptosis [30]. In our results, PDBD downregulates the expression of XIAP, Bcl-2, Bcl-xL and survivin at $12 \mathrm{~h}$ onwards in MDA 231 cells, however, in MCF-7 cells there were no changes in the expression levels of Bcl-2, but survivin, Bcl-xL and XIAP were down-regulated following treatment with PDBD at $24 \mathrm{~h}$ (Figure 7A). The JNK and p38 MAP kinase pathway proteins are associated with pro-survival as well as pro-apoptotic functions [31] and therefore the expression levels of pJNK and pp38 were investigated. The up regulation of pJNK were found from $3 \mathrm{~h}$ onwards in MCF-7 and MDA 231 cells, however, pp38 was upregulated at $3 \mathrm{~h}$ in MCF-7 cells and at $12 \mathrm{~h}$ MDA 231 cells (Figure 7B). Also, PDBD induced caspase3 activation ( $\sim 3.1$-fold) in MDA 231 cells (Figure 7C) sug-

\section{MCF-7}

MDA 231
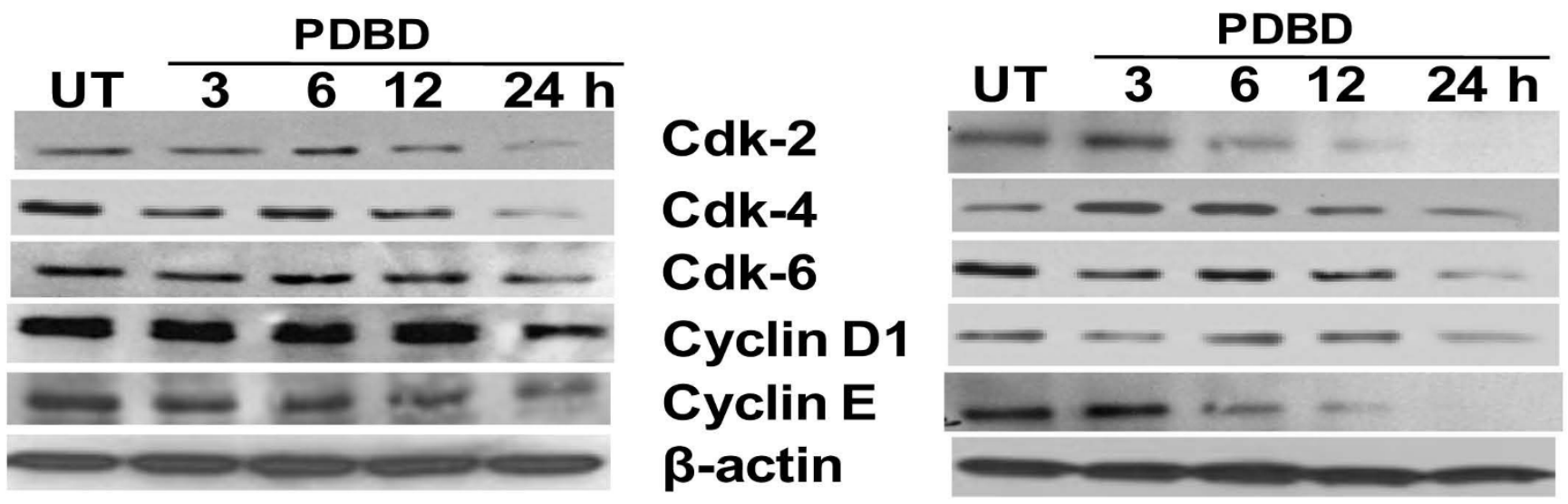

Figure 3

MCF-7 and MDA 23 I cells were treated with PDBD and cell lysates were subjected to Western blot analysis using cdk-2, cdk-4, cdk-6, Cyclin DI and Cyclin E. $\beta$-actin was used as a loading control. 
A

MCF-7

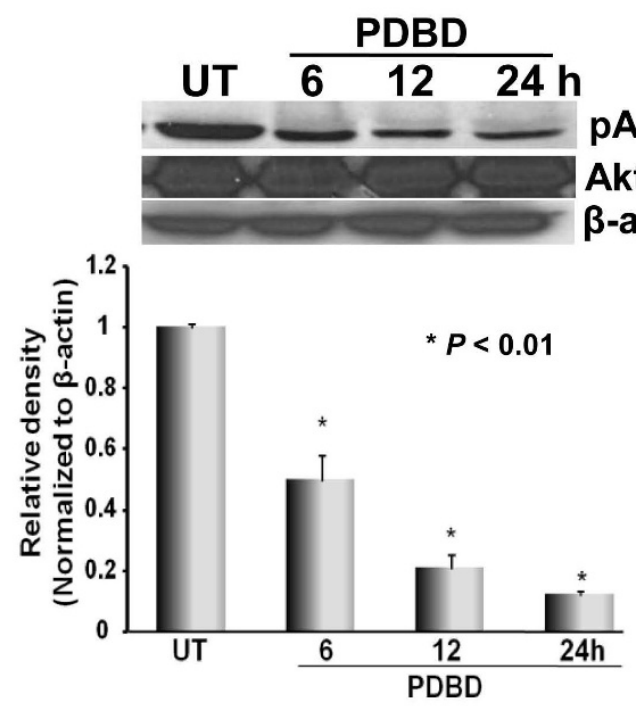

MDA 231

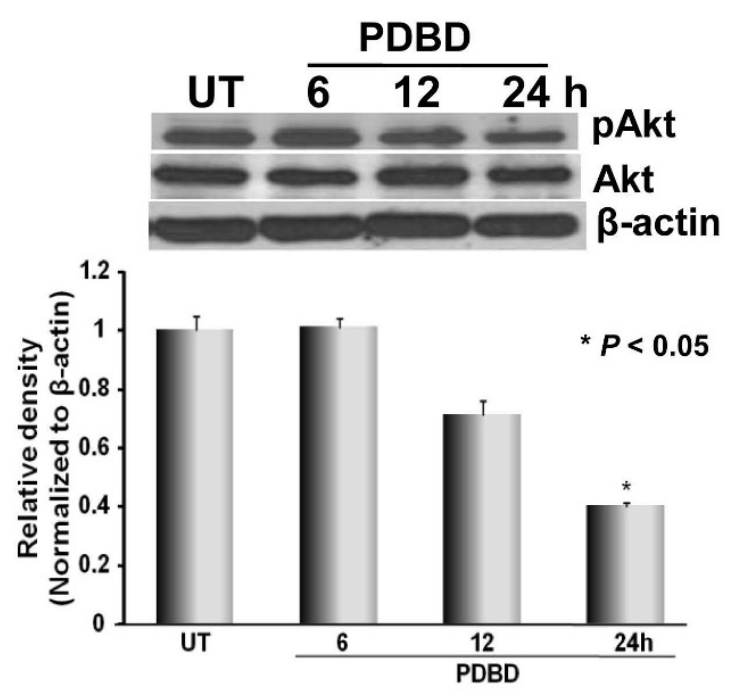

B

MCF-7

MDA 231

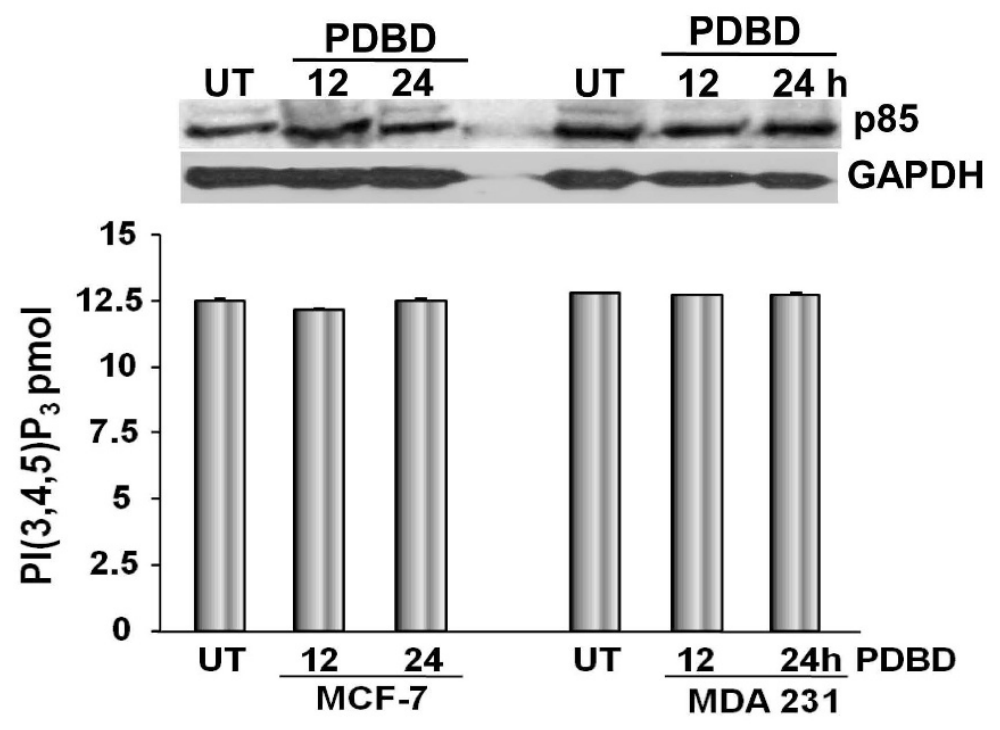

Figure 4

A. MCF-7 and MDA 23 I cells were treated with PDBD and cell lysates were subjected to Western blot analysis (upper panel) using pAkt (ser473) and Akt. Lower panel are the bar graphs representing the relative density of $p A k t$ in MCF-7 and MDA 23 I cells that were normalized with $\beta$-actin. B. MCF-7 and MDA 23 I cell lysates were subjected to Western blot analysis (upper panel) or colorimetric assay (lower panel) using PI3K antibody. 

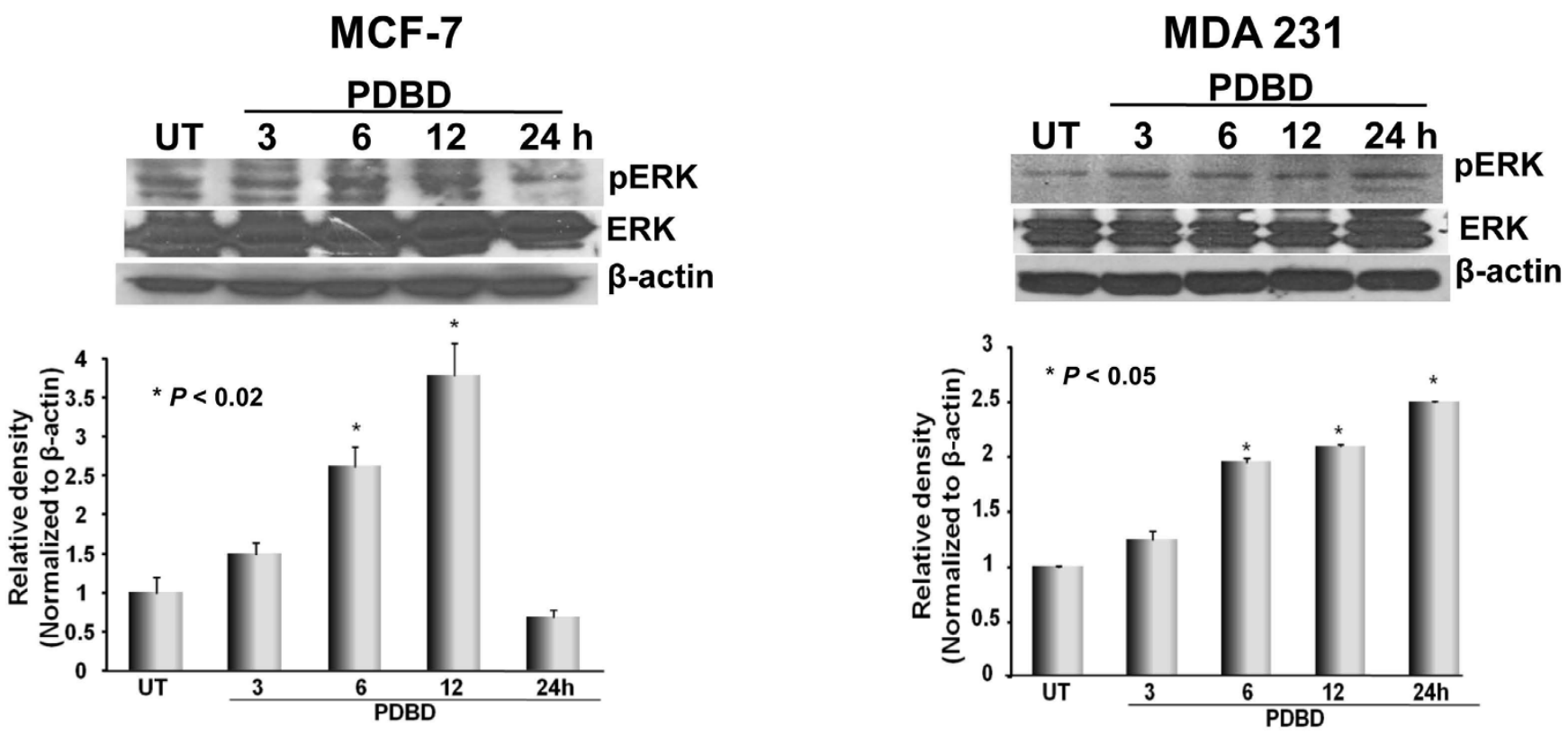

Figure 5

MCF-7 and MDA 23 I cells were treated with PDBD and subjected to Western blot analysis using pERK and ERK. Lower panel are the bar graphs representing the relative density of pERK in MCF-7 and MDA 23 I cells that were normalized with $\beta$-actin.

gesting that PDBD induces JNK- and p38-mediated proapoptotic signaling in $\mathrm{BCa}$.

\section{Discussion}

Discovery of active compounds from natural products have gained enormous importance in the field of $\mathrm{BCa}$ therapy. In the present study, we have identified a potent compound PDBD from a polyherbal mixture which specifically targets BCa cells without causing adverse effects on normal breast epithelial cells. Interestingly, our results suggest that ZR-75-1 cells are more sensitive when compared to MCF-7 cells, which may be due to the absence of caspase-3 in MCF-7 cells. The difference in PDBD sensitivity in MDA 231 and MDA 435 cells may be due to the over expression of Erb-B2 in MDA 435, which regulates cell survival and proliferation in several cancer types including BCa [32-35].

Dysregulation of the expression of the cyclins and cdks are involved in cell cycle, and which has been found to be a hallmark in various types of cancer. Cyclin D1, a component subunit of Cdk-4 and Cdk-6, is a rate-limiting factor in progression of cells through the first gap $\left(G_{1}\right)$ phase of the cell cycle [36]. Downregulation of Cdk-2, Cdk-4, Cdk6, Cyclin E, Cyclin D1 expression by PDBD suggests that it targets several cell cycle regulatory proteins in BCa cells.

The serine/threonine protein kinase, Akt, plays critical role in mammalian cell survival and has been shown to be activated in various cancers including BCa $[37,38]$. Some clinical studies suggested that activation of Akt correlates with HER-2 expression and these patients tend to have higher rate of relapse to tamoxifen therapy [39-42]. Recent studies report $15 \%-30 \%$ of BCa patient's express high pAkt levels which was associated with resistance to chemotherapeutic agents. The ability of PDBD to inhibit pAkt expression in our study suggests that either PDBD alone or a combination of PDBD with other chemotherapeutic agents like tamoxifen and doxorubicin may enhance the therapeutic potential of current chemotherapy drugs $[43,44]$. While dissecting the involvement of PI3K-mediated Akt signaling, we found that PDBD fails to alter the expression and kinase activity of PI3K in MCF-7 and MDA 231 cells. Though, MDA 231 cells were more sensitive to PDBD when compared to MCF-7 cells, pAkt expression was not significantly downregulated in MDA 231 cells suggesting that PDBD directly targets the downstream events of PI3K/Akt signaling in MDA 231 cells.

NF- $\kappa$ B activation regulates cell survival $[45,46]$ and it also simultaneously inhibits the expression of several proapoptotic proteins in various cell types $[3,47]$. In our studies we found that PDBD inhibited phosphorylation of Akt in MCF-7 cells when compared to MDA 231 cells; so we intended to determine whether PDBD regulates Akt downstream events which may possibly result in inhibition of cell survival. Several lines of evidence suggest a constitutive overexpression of $\mathrm{NF}-\kappa \mathrm{B}$ in ER- BCa com- 
A
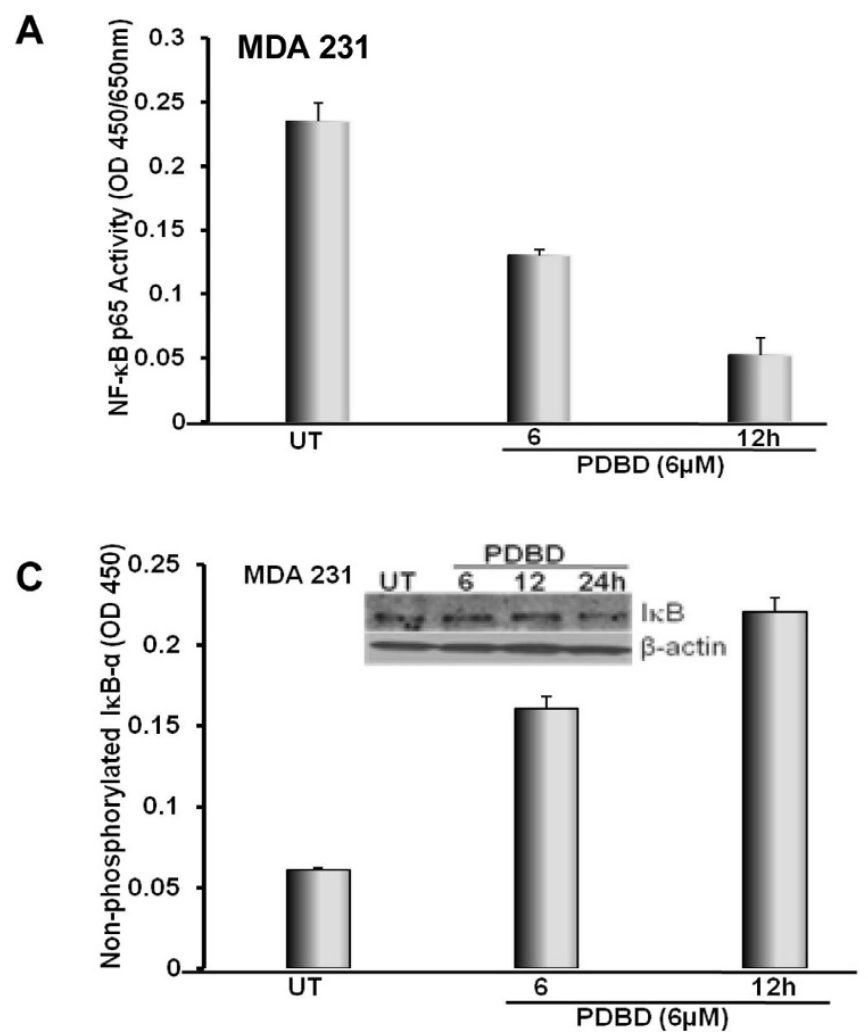

B

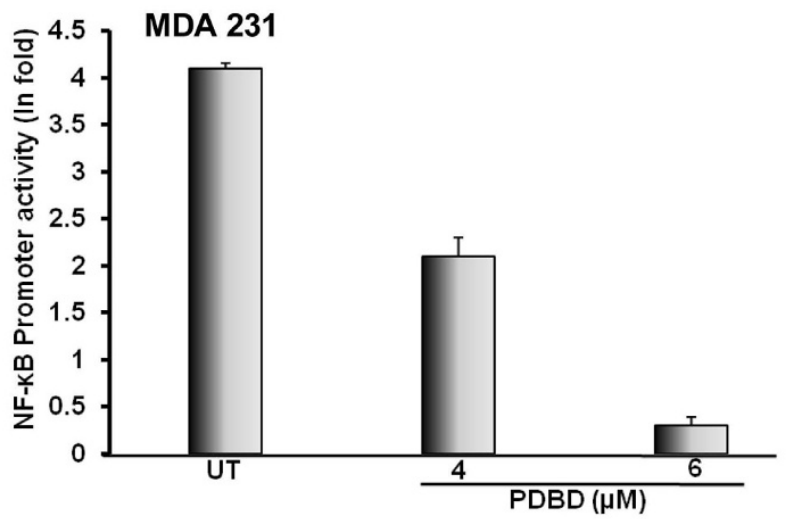

D

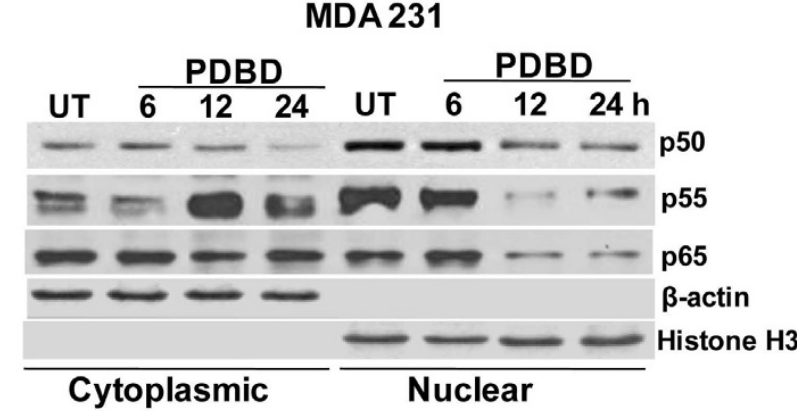

Figure 6

A. MDA 23 I cells treated with PDBD and subjected to NF- $\kappa B$ binding assay and NF- $\kappa B$ p 65 activity was studied to determine DNA binding activity. B. MDA 23 I cells were transiently transfected with NF- $\mathrm{KB}$-luc, treated with varying concentrations of PDBD for $24 \mathrm{~h}$ and reporter studies were performed to determine NF- $\kappa B$ promoter activity. pRL-TK was used as the rennilla control plasmid. C. MDA 23I cells were treated with PDBD and lysates were subjected to either Western blot analysis (upper panel) or ELISA (lower panel) for expression profile of non-phosphorylated IKB- $\alpha$. D. Nuclear and cytoplasmic fractions were obtained from MDA-23I cells, which were subjected to Western blot analysis using NF-kB p50, p55 and $\mathrm{p} 65$. $\beta$-actin was used as the loading control for cytoplasmic fraction and Histone $\mathrm{H} 3$ was used as the loading control for nuclear fraction.

pared to $\mathrm{ER}^{+} \mathrm{BCa}[48-50]$. The p65 subunit of NF- $\mathrm{KB}$ is overexpressed in most of the $\mathrm{BCa}$ cell lines and in $\mathrm{BCa}$ tumor tissues [48]. Interestingly a higher percentage of NF- $\mathrm{KB}$ activation $(98.7 \%)$ was found in human BCa tissues from Taiwanese women which was correlated with higher percentage of patients with metastatic BCa [51]. In our study, PDBD inhibited NF- $\mathrm{BB}$ activation at the promoter and protein level in MDA 231 cells suggesting that PDBD can be used as a potential therapeutic agent for BCa. Several natural compounds have the ability to downregulate NF- $\mathrm{\kappa B}$ activation and some of the compounds that we investigated in our laboratory namely curcumin [22], Withaferin A [26] and Psoralidin [24], also shown the ability to downregulate the NF- $\mathrm{kB}$ activation in many cancer types.

Increased expression of phosphorylated JNK and p38 by PDBD in both MCF-7 and MDA 231 cells suggest that acti- vated JNK and p38 play a role in the induction of apoptosis in BCa cells [52]. Descriptively, the inhibition of Akt pathway and the simultaneous activation of p38/JNK pathway may attribute to the anti cancer activity of PDBD in BCa cells. It is important to investigate whether inhibition of cell proliferation and induction of apoptosis by PDBD is associated with the down-regulation of pro-survival signaling. Our results suggest that PDBD downregulates the expression of XIAP, Bcl-xL and surviving which might lead to chemosensitization of BCa cells.

\section{Conclusion}

PDBD inhibits pro-survival signaling such as Akt, MEK and NF- $\kappa \mathrm{B}$ with a simultaneous induction of pro-apoptotic proteins in the $\mathrm{BCa}$ cells resulting in inhibition of cell survival and proliferation. Additionally, PDBD causes a $\mathrm{G}_{0} / \mathrm{G}_{1}$ cell cycle arrest in both MDA 231 and MCF-7 cells which is also an important aspect for the treatment of can- 
A
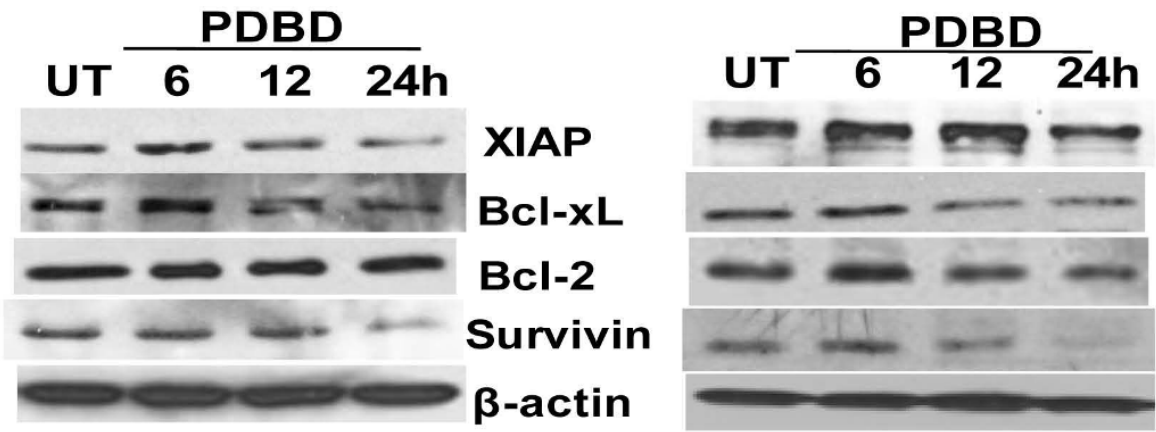

B
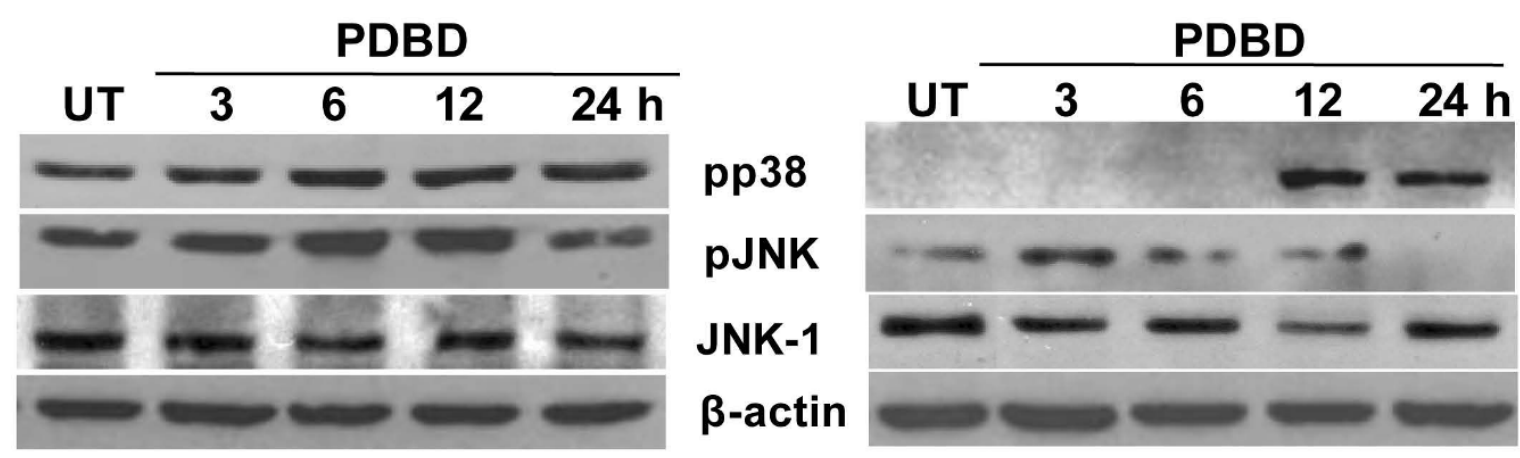

C

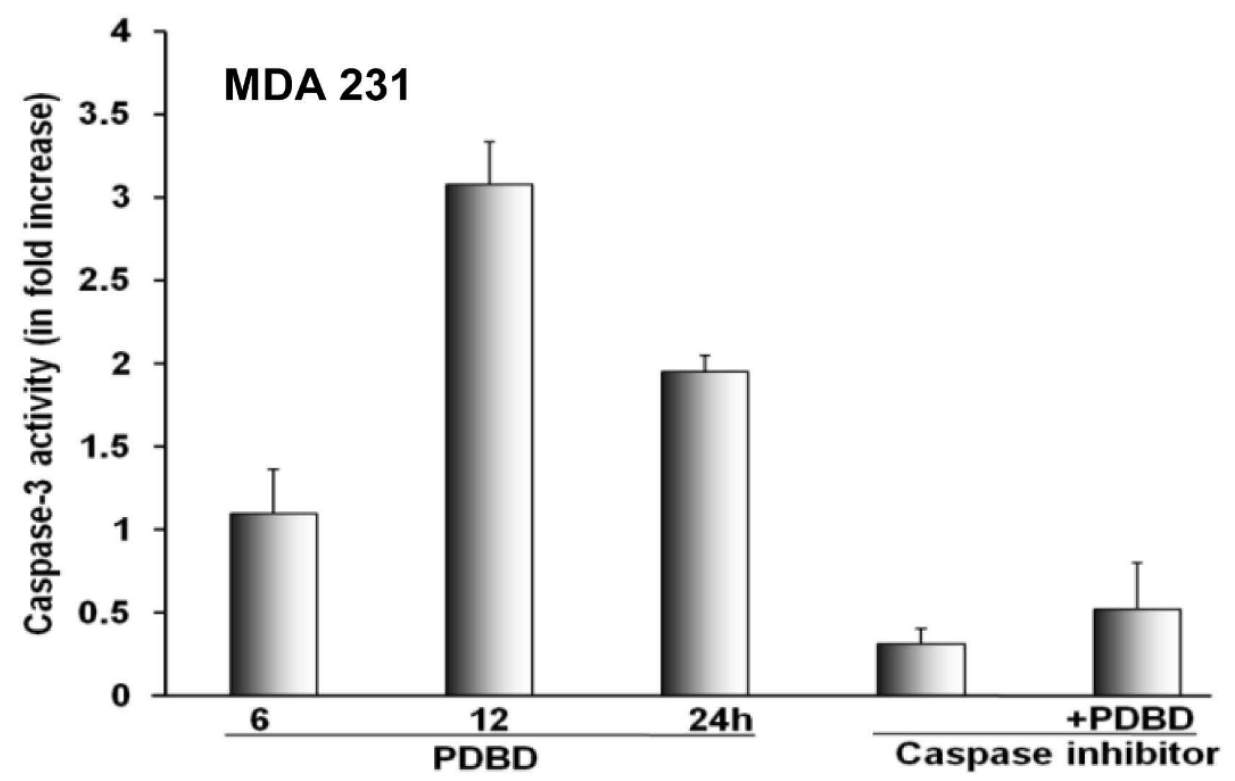

Figure 7

A. MDA 23 I cells treated with PDBD and cell lysates were subjected to Western blot analysis using XIAP, Bcl$\mathbf{x L}, \mathbf{B c l}-2$ and survivin. B. Western blot analysis using pp38, pJNK, JNK-I expression in MCF-7 and MDA 23 I cells. C. MDA 231 cells were treated with PDBD alone, caspase inhibitor alone or a combination of PDBD and caspase inhibitor for varying time intervals and were subjected to caspase- 3 activation studies using flourometric assay. 
cer. Collectively our results suggest that further investigation of PDBD in vivo models may help bring this potent molecule into the main stream of medicine for the treatment of BCa.

\section{Abbreviations}

BCa: breast cancer; ER: estrogen receptor; PDBD: (8'Z)-3pentadec-10-enyl-benzene-1, 2-diol; IAP: inhibitors of apoptosis protein; MAPK: Mitogen activated protein kinase; ERK: extracellular-regulated kinase; JNK: c-Jun Nterminal kinase; PI3K: Phosphotidyl Inositide-3-Kinase.

\section{Competing interests}

The authors declare that they have no competing interests.

\section{Authors' contributions}

SK, SS, RK and RG performed experiments. JR and CD designed the experiments, prepare the manuscript and supervised the project. All authors read and approved the final manuscript.

\section{Acknowledgements}

This work was supported by the grant from the Susan G. Komen Breast Cancer Foundation to $C D$.

\section{References}

I. Andre F, Slimane K, Bachelot T, Dunant A, Namer M, Barrelier A, Kabbaj O, Spano JP, Marsiglia H, Rouzier R, et al.: Breast cancer with synchronous metastases: trends in survival during a I4year period. J Clin Oncol 2004, 22( I 6):3302-3308.

2. Marsh S, McLeod HL: Pharmacogenetics and oncology treatment for breast cancer. Expert Opin Pharmacother 2007, 8(2): I I9-127.

3. Brunet A, Bonni A, Zigmond MJ, Lin MZ, Juo P, Hu LS, Anderson MJ, Arden KC, Blenis J, Greenberg ME: Akt promotes cell survival by phosphorylating and inhibiting a Forkhead transcription factor. Cell 1999, 96(6):857-868.

4. Cross DA, Alessi DR, Cohen P, Andjelkovich M, Hemmings BA: Inhibition of glycogen synthase kinase- 3 by insulin mediated by protein kinase B. Nature 1995, 378(6559):785-789.

5. Kennedy SG, Kandel ES, Cross TK, Hay N: Akt/Protein kinase B inhibits cell death by preventing the release of cytochrome $C$ from mitochondria. Mol Cell Biol I999, I9(8):5800-58I0.

6. Hennessy BT, Smith DL, Ram PT, Lu Y, Mills GB: Exploiting the PI3K/AKT pathway for cancer drug discovery. Nat Rev Drug Discov 2005, 4(12):988-1004

7. Diehl JA, Cheng M, Roussel MF, Sherr CJ: Glycogen synthase kinase-3beta regulates cyclin DI proteolysis and subcellular localization. Genes Dev 1998, I 2(22):3499-35 I I

8. Zhou BP, Liao Y, Xia W, Spohn B, Lee MH, Hung MC: Cytoplasmic localization of p2 I Cip I/WAFI by Akt-induced phosphorylation in HER-2/neu-overexpressing cells. Nat Cell Biol 200I, 3(3):245-252.

9. Viglietto G, Motti ML, Bruni P, Melillo RM, D'Alessio A, Califano D, Vinci F, Chiappetta G, Tsichlis P, Bellacosa A, et al.: Cytoplasmic relocalization and inhibition of the cyclin-dependent kinase inhibitor p27(Kip I) by PKB/Akt-mediated phosphorylation in breast cancer. Nat Med 2002, 8( I 0): I I 36- I | 44.

10. Varnai P, Bondeva T, Tamas P, Toth B, Buday L, Hunyady L, Balla T: Selective cellular effects of overexpressed pleckstrin-homology domains that recognize $\mathrm{Ptdlns}(3,4,5) \mathrm{P} 3$ suggest their interaction with protein binding partners. I Cell Sci 2005, I I 8(Pt 20):4879-4888.

II. Santen RJ, Song RX, McPherson R, Kumar R, Adam L, Jeng MH, Yue $W$ : The role of mitogen-activated protein (MAP) kinase in breast cancer. J Steroid Biochem Mol Biol 2002, 80(2):239-256.
12. Seddighzadeh M, Zhou JN, Kronenwett U, Shoshan MC, Auer G, Sten-Linder M, Wiman B, Linder S: ERK signalling in metastatic human MDA-MB-23 I breast carcinoma cells is adapted to obtain high urokinase expression and rapid cell proliferation. Clin Exp Metastasis 1999, I 7(8):649-654.

13. Sewing A, Wiseman B, Lloyd AC, Land H: High-intensity Raf signal causes cell cycle arrest mediated by p2ICipl. Mol Cell Biol 1997, I 7(9):5588-5597.

14. Johnson GL, Lapadat R: Mitogen-activated protein kinase pathways mediated by ERK, JNK, and p38 protein kinases. Science 2002, 298(5600): 1911-1912.

15. Singh DK, Lippman SM: Cancer chemoprevention. Part I: Retinoids and carotenoids and other classic antioxidants. Oncology (Williston Park) 1998, I 2(I I): I 643-1653.

16. Fotsis T, Pepper MS, Aktas E, Breit S, Rasku S, Adlercreutz H, Wahala $\mathrm{K}$, Montesano R, Schweigerer L: Flavonoids, dietary-derived inhibitors of cell proliferation and in vitro angiogenesis. Cancer Res 1997, 57(14):2916-2921.

17. Goodman GE: The clinical evaluation of cancer prevention agents. Proc Soc Exp Biol Med 1997, 2 I 6(2):253-259.

18. Singh RP, Agarwal R: Flavonoid antioxidant silymarin and skin cancer. Antioxid Redox Signal 2002, 4(4):655-663.

19. Sowmyalakshmi S, Nur EAM, Akbarsha MA, Thirugnanam S, Rohr J Chendil D: Investigation on Semecarpus Lehyam-a Siddha medicine for breast cancer. Planta 2005, 220(6):910-918.

20. Zhao W, Zhu L, Srinivasan S, Damodaran C, Rohr J: Identification of Urushiols as the Major Active Principle of the Siddha Herbal Medicine Semecarpus Lehyam: Anti-tumor Agents for the treatment of Breast Cancer. Pharmaceutical Biology in press.

2I. Butler R, Mitchell SH, Tindall DJ, Young CY: Nonapoptotic cell death associated with S-phase arrest of prostate cancer cells via the peroxisome proliferator-activated receptor gamma ligand, I 5-deoxy-delta I 2, I 4-prostaglandin J2. Cell Growth Differ 2000, I I ( I):49-6I

22. Chendil D, Ranga RS, Meigooni D, Sathishkumar S, Ahmed MM: Curcumin confers radiosensitizing effect in prostate cancer cell line PC-3. Oncogene 2004, 23(8): I 599- 1607.

23. Ranga RS, Girija R, Nur-e-Alam M, Sathishkumar S, Akbarsha MA, Thirugnanam S, Rohr J, Ahmed MM, Chendil D: Rasagenthi lehyam (RL) a novel complementary and alternative medicine for prostate cancer. Cancer Chemother Pharmacol 2004, 54(I):7-I5.

24. Raj Kumar, Sowmyalakshmi Srinivasan, Srinivas Koduru, Pallab Pahari, Jürgen Rohr, Kyprianou Natasha A, Chendil D: Psoralidin, An Herbal Molecule Inhibits PI3K Mediated Akt Signaling In Androgen Independent Prostate Cancer (AIPC) Cells. Cancer Prevention Research 2008 in press.

25. Gupta S, Hastak K, Afaq F, Ahmad N, Mukhtar H: Essential role of caspases in epigallocatechin-3-gallate-mediated inhibition of nuclear factor kappa B and induction of apoptosis. Oncogene 2004, 23( ( 4):2507-2522.

26. Srinivasan S, Ranga RS, Burikhanov R, Han SS, Chendil D: Par-4dependent apoptosis by the dietary compound withaferin $A$ in prostate cancer cells. Cancer Res 2007, 67(I):246-253.

27. El-Guendy N, Zhao Y, Gurumurthy S, Burikhanov R, Rangnekar VM: Identification of a unique core domain of par-4 sufficient for selective apoptosis induction in cancer cells. Mol Cell Biol 2003, 23( 1 6):5516-5525.

28. Hanahan D, Weinberg RA: The hallmarks of cancer. Cell 2000, I 00(I):57-70

29. Li X, Massa PE, Hanidu A, Peet GW, Aro P, Savitt A, Mische S, Li J, Marcu KB: IKKalpha, IKKbeta, and NEMO/IKKgamma are each required for the NF-kappa B-mediated inflammatory response program. Jiol Chem 2002, 277(47):45 I29-45 I 40.

30. Youle RJ, Strasser A: The BCL-2 protein family: opposing activities that mediate cell death. Nat Rev Mol Cell Biol 2008 , 9(I):47-59.

3I. Yang SR, Cho SD, Ahn NS, Jung JW, Park JS, Jo EH, Hwang JW, Kim $\mathrm{SH}$, Lee $\mathrm{BH}$, Kang KS, et al.: The role of p38 MAP kinase and cJun $\mathbf{N}$-terminal protein kinase signaling in the differentiation and apoptosis of immortalized neural stem cells. Mutat Res 2005, 579(I-2):47-57.

32. Price JE, Polyzos A, Zhang RD, Daniels LM: Tumorigenicity and metastasis of human breast carcinoma cell lines in nude mice. Cancer Res 1990, 50(3):717-72I. 
33. Lupu R, Colomer R, Zugmaier G, Sarup J, Shepard M, Slamon D, Lippman ME: Direct interaction of a ligand for the erbB2 oncogene product with the EGF receptor and p 185 erbB2. Science 1990 , 249(4976): I552-I555.

34. Bacus SS, Huberman E, Chin D, Kiguchi K, Simpson S, Lippman M, Lupu R: A ligand for the erbB-2 oncogene product (gp30) induces differentiation of human breast cancer cells. Cell Growth Differ 1992, 3(7):401-4II.

35. Neve RM, Sutterluty H, Pullen N, Lane HA, Daly JM, Krek W, Hynes NE: Effects of oncogenic ErbB2 on $\mathrm{GI}$ cell cycle regulators in breast tumour cells. Oncogene 2000, 19(13): 1647-1656.

36. Baldin V, Lukas J, Marcote MJ, Pagano M, Draetta G: Cyclin DI is a nuclear protein required for cell cycle progression in $\mathbf{G I}$. Genes Dev 1993, 7(5):812-82I.

37. Clarke RB: p27KIPI phosphorylation by PKB/Akt leads to poor breast cancer prognosis. Breast Cancer Res 2003, 5(3): 162-163

38. Chang F, Lee JT, Navolanic PM, Steelman LS, Shelton JG, Blalock WL Franklin RA, McCubrey JA: Involvement of PI3K/Akt pathway in cell cycle progression, apoptosis, and neoplastic transformation: a target for cancer chemotherapy. Leukemia 2003 , 17(3):590-603.

39. Tokunaga E, Kimura $Y$, Oki E, Ueda N, Futatsugi M, Mashino K, Yamamoto M, lkebe M, Kakeji $Y, B a b a ~ H$, et al.: Akt is frequently activated in HER2/neu-positive breast cancers and associated with poor prognosis among hormone-treated patients. Int J Cancer 2006, I I 8(2):284-289.

40. Kirkegaard T, Witton C], McGlynn LM, Tovey SM, Dunne B, Lyon A, Bartlett JM: AKT activation predicts outcome in breast cancer patients treated with tamoxifen. J Pathol 2005, 207(2): I 39- I 46.

41. Sastre-Garau X, Genin P, Rousseau A, Al Ghuzlan A, Nicolas A, Freneaux P, Rosty C, Sigal-Zafrani B, Couturier J, Thiery JP, et al.: Increased cell size and Akt activation in HER-2/neu-overexpressing invasive ductal carcinoma of the breast. Histopathology 2004, 45(2): I $42-147$.

42. Schmitz KJ, Otterbach F, Callies R, Levkau B, Holscher M, Hoffmann $\mathrm{O}$, Grabellus F, Kimmig R, Schmid KW, Baba HA: Prognostic relevance of activated Akt kinase in node-negative breast cancer: a clinicopathological study of 99 cases. Mod Pathol 2004, I7(I):|5-2I.

43. Roudier E, Mistafa $O$, Stenius U: Statins induce mammalian target of rapamycin (mTOR)-mediated inhibition of Akt signaling and sensitize p53-deficient cells to cytostatic drugs. Mol Cancer Ther 2006, 5(II):2706-27I5.

44. Mondesire $\mathrm{WH}$, Jian W, Zhang $\mathrm{H}$, Ensor J, Hung MC, Mills GB, MericBernstam $F$ : Targeting mammalian target of rapamycin synergistically enhances chemotherapy-induced cytotoxicity in breast cancer cells. Clin Cancer Res 2004, I 0(20):703 I-7042.

45. Ozes ON, Mayo LD, Gustin JA, Pfeffer SR, Pfeffer LM, Donner DB: NF-kappaB activation by tumour necrosis factor requires the Akt serine-threonine kinase. Nature 1999 40 I (6748):82-85.

46. Romashkova JA, Makarov SS: NF-kappaB is a target of AKT in anti-apoptotic PDGF signalling. Nature 1999, 40 I(6748):86-90.

47. Cardone MH, Roy N, Stennicke HR, Salvesen GS, Franke TF, Stanbridge E, Frisch S, Reed JC: Regulation of cell death protease caspase-9 by phosphorylation. Science 1998, 282(5392): $|3| 8-|32|$.

48. Nakshatri H, Bhat-Nakshatri P, Martin DA, Goulet RJ Jr, Sledge GW Jr: Constitutive activation of NF-kappaB during progression of breast cancer to hormone-independent growth. Mol Cell Biol 1997, 17(7):3629-3639.

49. Sovak MA, Bellas RE, Kim DW, Zanieski GJ, Rogers AE, Traish AM, Sonenshein GE: Aberrant nuclear factor-kappaB/Rel expression and the pathogenesis of breast cancer. J Clin Invest 1997. I 00( I 2):2952-2960.

50. Dejardin E, Deregowski V, Chapelier M, Jacobs N, Gielen J, Merville MP, Bours V: Regulation of NF-kappaB activity by I kappaBrelated proteins in adenocarcinoma cells. Oncogene 1999 , I 8( I 6):2567-2577.

5I. Hou MF, Lin SB, Yuan SS, Tsai SM, Wu SH, Ou-Yang F, Hsieh JS, Tsai $K B$, Huang TJ, Tsai LY: The clinical significance between activation of nuclear factor kappa $B$ transcription factor and overexpression of HER-2/neu oncoprotein in Taiwanese patients with breast cancer. Clin Chim Acta 2003, 334(I-2): |37-| 44.
52. Heasley LE, Han SY: JNK regulation of oncogenesis. Mol Cells 2006, 21 (2):167-173.

\section{Pre-publication history}

The pre-publication history for this paper can be accessed here:

http://www.biomedcentral.com/1471-2407/9/41/prepub
Publish with Bio Med Central and every scientist can read your work free of charge

"BioMed Central will be the most significant development for disseminating the results of biomedical research in our lifetime. "

Sir Paul Nurse, Cancer Research UK

Your research papers will be:

- available free of charge to the entire biomedical community

- peer reviewed and published immediately upon acceptance

- cited in PubMed and archived on PubMed Central

- yours - you keep the copyright
BioMedcentral 